\title{
PSYCHOLOGICAL ASPECTS OF DECISION-MAKING IN RISK
}

У статті проаналізовано концептуальні положення представників психологічноі науки в рамках поняття «прийняття рішення» та визначено вплив психологічних аспектів на прийняття рішення в умовах ризику. Виокремлено зовнішні (соціокультурні та просторово-часові характеристики) та внутрішні фрактори (індивідуально-психологічні характеристики індивіда, його знання та досвід з певного питання), які впливають на прийняття рішень. Визначено компоненти прийняття рішення: ціль, боротьба мотивів, активність та свідомість, з чого слідує, що кожен вольовий акт містить у собі рішення, оскільки він передбачає прийняття певної мети і відкриває відповідному бажанню доступ до моторної сорери, до дій, спрямованих на їі реалізацію. Визначено, що здатність людей потрапляти під вплив різноманітних емоцій, пов'язаних з ризиком, зумовлює появу рішень, які можуть докорінно змінити поведінку особистості. Ситуація ризику передбачає наявність не лише об'єктивних, але і суб'єктивних чинників ї буття. Суб'єктивна ії частина пов'язана з вибором альтернатив, різним сприйняттям індивідами однієї і тієї ж величини ризику. Відзначено, що схильність до ризиків зменшується, коли людині нав'язують вибір та коли їй доручено прийняти рішення. В таких випадках особистість не хоче ризикувати тому надалі відповідальність за прийняте рішення може бути покладена саме на неї. Таким чином, у людей в умовах добровільного або нав'язаного вибору виникає двояке відношення до ризику. Якщо людині настирливо рекомендувати прийняття того чи іншого рішення, вона взагалі може відмовитись від його приймання. Визначено, що під час прийняття рішень в умовах ризику важливо враховувати такий фактор, як час. Знаходячись в умовах часової обмеженості, ризику та стресу, емоційний стан людини зазнає навантаження, що може вплинути на коректність прийняття рішення та призвести до небажаних наслідків.
Ключові слова: прийняття рішення, ризик, мета, мотив, умови ризику.

The article analyzes the conceptual provisions of the representatives of psychological science within the concept of "decision making" and identifies the impact of psychological aspects on decision making in terms of risk. External (socio-cultural and spatio-temporal characteristics) and internal factors (individual-psychological characteristics of the individual, his knowledge and experience on a particular issue) that influence decision-making are identified. The components of decision-making are defined: purpose, struggle of motives, activity and consciousness, which means that every volitional act includes a decision, because it involves a certain goal and gives access to the desired desire to the motor sphere, to actions aimed at its implementation. It has been established that the ability of people to be affected by various emotions associated with risk, leads to the emergence of solutions that can radically change the behavior of the individual. The situation of risk presupposes the presence of not only objective but also subjective factors of its existence. The subjective part of it is related to the choice of alternatives, different perceptions of individuals of the same amount of risk. It is noted that the propensity to take risks decreases when a person is forced to make a choice and when he is instructed to make a decision. In these cases, the individual does not want to take risks, so in the future the responsibility for the decision may be placed on him. Thus, people with voluntary or forced choices have a dual attitude to risk. If a person is insistently recommended to make a decision, he may refuse to make it at all. It is determined that when making decisions in conditions of risk, it is important to take into account such a factor as time. Being in conditions of time constraints and conditions of risk and stress, a person's emotional state is subjected to stress, which can affect the correctness of decision-making and lead to undesirable consequences.

Key words: decision making, risk, purpose, motive, risk conditions.
Постановка проблеми. Прийняття рішень особистістю в різних життєвих ситуаціях та за варіативністю умов $є$ одним із факторів психологічних досліджень. Сьогодні багато рішень приймається в умовах ризику та стресових ситуаціях, що потребує більш детального розгляду.

Роль психології як науки в понятті «прийняття рішення» зростає, що зумовлено зміною акценту проблематики 3 об'єктивних механізмів отриманих рішень на суб'єктивні.

Прийняття рішення в умовах ризику як процесу в психологічній науці має собою певний інтерес: з одного боку, це дає змогу краще зрозуміти поведінку особистості, що приймає рішення, а з іншого - дає змогу розробити рекомендації щодо правильності прийняття рішень в тій чи іншій ситуації та мати певні прогностичні оцінки для подальших досліджень.

Залежно від виду діяльності та умов прийняття рішення може протікати в необмеженому часовому проміжку або обмеженому, де в особистості можуть спостерігатись зміни у психічному стані. Як наслідок, прийняття рішення може ускладнюватись.

Аналіз останніх досліджень і публікацій. Проблематикою питання 3 врахування психологічних аспектів під час прийняття рішень в умовах ризику займались такі дослідники та вчені, як В. Боснюк, Н. Гурова, І. Дженіс, Е. Етціоні, А. Ісмаілов, І. Киштимова, А. Леонтьєв, Л. Манн, М. Мескон, С. Пашкевич, 
С. Плаус, О. Ренн, Дж. Роттер, С. Рубінштейн, І. Шавкунова.

Постановка завдання. Мета статті - проаналізувати концептуальні положення представників психологічної науки в рамкахпоняття «прийняття рішення» та визначити вплив психологічних аспектів на прийняття рішення в умовах ризику.

Виклад основного матеріалу дослідження. Прийняття рішень $€$ невіддільним складником життя людини, з яким вона стикається як в повсякденній, так і в професійній діяльності.

У психології поняття «прийняття рішення» трактується як «етап вольового акту, пов'язаний з вибором мети і способу дій» [1, с. 369]. Попередньо згадана дефініція в зарубіжній науковій літературі трактується двома термінами:

A) decision making - «пізнавальний процес вибору між двома або більше альтернативами, починаючи від відносно чіткого (наприклад, замовлення їжі в ресторані) і закінчуючи складним (наприклад, вибором партнера)» [15].

Б) problem solving - «процес, за допомогою якого люди намагаються подолати труднощі, домогтися планів, які рухають їх від вихідної ситуації до бажаної мети, або роблять висновки за допомогою використання вищих психічних функцій, таких як міркування та творче мислення» [15].

Під час вирішення якогось питання, завдання або проблеми на людину впливає ряд факторів як зовнішнього, так і внутрішнього середовища. До факторів внутрішнього середовища можна віднести індивідуально-психологічні характеристики індивіда, його знання та досвід з певного питання, що потребує вирішення. До зовнішніх факторів можна віднести соціокультурні та просторово-часові характеристики, що безпосередньо виливають на прийняття рішення.

В. Боснюк у статті «Проблема прийняття рішень у ризиконебезпечних умовах діяльності» зазначає, що в «класичній теорії прийняття рішень розрізняють прийняття рішень в умовах визначеності, невизначеності та ризику» [2].

До прийняття рішень в умовах визначеності належить раціональна модель і вибір людини $€$ однозначним, тобто людина з чітко визначених альтернатив обирає саме ту, завдяки якій він отримає необхідну вигоду.

Для прийняття рішень в умовах невизначеності, яка може бути повною або частковою, характерно те, що людина не може однозначно сказати або передбачити, що трапиться після її вибору. Тут людина дотримується евристичних стратегій прийняття рішень.

Прийняття рішення в умовах ризику часто ототожнюється 3 невизначеністю. «Невизначеність трапляється лише в тому разі, коли ймовірність настання кінцевого рішення неві- дома. Прийняття рішень в умовах ризику припускає введення ймовірності в інформацію. Людина точно не знає, якого стану досягне, не знає розподілу ймовірності на можливі досягнення» [2].

Можна розглянути як у різних галузях психологічної науки розглядається розуміння процесу прийняття рішення.

У психосеміотичній парадигмі, як зазначає І. Киштимова, «прийняття рішень пов'язується зі здатністю до творчого осмислення завдання, породження альтернатив, які своєю чергою залежать від рівня смислового розвитку особистості і її умінь актуалізувати ці особистісні смисли в мовному або предметному продукті діяльності» [7]. Варто погодитись з автором, що, маючи низький рівень розвитку ментальних та психічних здібностей, людині важче буде прийняти рішення, аніж людині з високими показниками, особливо в умовах ризику.

Також автор додає, що за такого підходу рішення «детерміновано більшою мірою не когнітивними, а особистісними, смисловими факторами, здатністю до бачення завдання з різних сторін і продукування множинних варіантів її вирішення і вибору найбільш цінного з них. Причому цінність розуміється як системне поняття, нижній рівень якого пов'язаний з побутовими, а верхній - з буттєвими, екзистенційними смислами» [7]. Кожна людина має свою систему ціннісних орієнтирів і, підходячи до вирішення аналогічних проблем, індивід А та індивід В можуть зробити різний вибір відповідно до їх найвищих цінностей.

У психолінгвістиці «прийняття рішення» розуміється як процес розпізнавання слів. Представник цієї галузі А. Леонтьєв говорить, що прийняття рішення зіставляється 3 «розумовою діяльністю індивіда в процесі сприйняття мови і розпізнання в ній окремих слів» [8]. А в інженерній психології це поняття «ототожнюється з ухваленням рішення щодо сприйняття сигналів і способів впливу на систему управління» [6].

У рамках когнітивної психології вченими вивчається та інформація, якою оперує людина в процесі прийняття рішення (особистого або групового) стосовно конкретної ситуації.

Н. Гурова в рамках своєї роботи «Психологія мислення» зазначає, що до здатності приймати рішення належить: "вміння орієнтуватися в ситуації, вилучати інформацію (базові дані), давати їй адекватну семантичну оцінку, вміння діяти відповідно до цієї оцінки, а не всупереч їй, тобто виявляти свободу інтелектуального вибору і при цьому домагатися найкращих результатів» [3].

Таким чином, прийняття рішення виступає як особливий вид психічної діяльності людини, який націлений на вибір способу та засобу досягнення поставленої мети. 
І. Шавкунова в своїй статті «Рішення» в психології та економіці: інтеграція наукових підходів» [13, с. 27-28] посилається на погляди С. Рубінштейна, який говорить, що прийняття рішення має такі компоненти, як ціль, боротьба мотивів, активність та свідомість, з чого слідує, що кожен вольовий акт містить у собі рішення, оскільки він передбачає прийняття певної мети і відкриває відповідному бажанню доступ до моторної сфери, до дій, спрямованих на її реалізацію.

Прийняття рішення має певну схему, і одним з перших, хто її розробив в психології, в рамках суб'єктно-діяльнісного підходу, був С. Рубінштейн. Він виділив чотири етапи особистісного прийняття рішення:

А) «поява спонукання та попередня постановка мети;

Б) етап обговорення та боротьби мотивів;

В) рішення;

Г) реалізація рішення» [12].

На першому етапі з'являється спонукання та усвідомлення мети, які $€$ між собою взаємопов'язаними відповідно до того, як людина усвідомлює мету, яка переходить в бажання. Тут передбачається наявність певного досвіду, за допомогою якого індивід дізнається, що саме та яким чином здатне задовольнити та реалізувати його бажання або потребу. Після формування бажання наступає фаза постановки цілі або мети.

У людини на другому етапі, за С. Рубінштейном, може відбуватись боротьба мотивів, тому що засоби, які ведуть до реалізації цілі, можуть призводити до небажаних наслідків поведінки. Як приклад можна привести бажану посаду на роботі, що є ціллю. Отримати її можна або підставивши колегу по роботі, що призведе до небажаних наслідків, або ж працювати наполегливо декілька років. Також на цьому етапі відбувається різностороння оцінка поставленої мети та її обговорення.

На третьому етапі відбувається завершальне встановлення цілі за допомогою рішення, що деколи може відрізнятись від першопокладеної цілі. На цьому етапі особистість «здійснює вибір одного з мотивів як вирішального, остаточно обирає мету своєї дії, усвідомлює наслідки цієї дії і відчуває почуття відповідальності за неї» [12]. Наступним кроком або етапом є перехід до дій та втілення прийнятого рішення, його реалізація.

Наступна схема прийняття рішення в психології була представлена С. Плаусом у його роботі «Психологія оцінки та прийняття рішення». Він наголошує на таких складниках процесу прийняття рішення, як:

А) «мета або цільова функція, сформульована в явному вигляді або мається на увазі;

Б) альтернативи - як гіпотези, результати, цінності, інформація;
В) критерії - як оцінки результатів, цінностей, інформації;

Г) стратегія - як схема оцінки альтернатив, результатів, цінності, інформації, критеріїв тощо;

Д) вибір - як зменшення альтернатив до однієї, і правила - як конкретна послідовність оцінок для забезпечення вибору» [10].

Вже попередньо згадувалось, що частина рішень, які приймаються у нашому житті, відбуваються в умовах ризику. Ризик сам по собі може сприйматись по-різному індивідом чи групою людей, де все залежить від «семантичного образу». На основі цього О. Ренн виділив чотири типи ризику залежно від суспільного сприйняття.

Перший тип - «Неминуча небезпека» належить до штучних джерел ризику, які мають катастрофічний потенціал. «Це така випадковість, яка викликає страх та бажання ії уникнути» [11]. До цього типу ризику не належать природні катастрофи, а більше ті випадки, які спричиняють техногенні катастрофи. Останні $\epsilon$ непередбачуваними, на відміну від природних, що є очікуваними в суспільстві.

Другий тип «Повільні вбивці» $€$ тієї категорією ризиків, які розглядаються як невидима загроза для благополуччя. Про ці ризики краще дізнатись зі сторони, аніж самому в них потрапити. Головною рисою в цих ризиках є «певний ступінь довіри до установ, які забезпечують інформацією та керують небезпекою» [11].

Третій тип ризиків «Співвідношення затрат вигоди». В цьому випадку індивід розглядає співвідношення доходів та втрат. Він більше характерний для фінансових справ, де є такі ризики.

Четвертий тип - «Любителі гострих відчуттів». До цього типу ризику належать люди, які шукають ризик, намагаються відчути та пережити ці емоції. «Ці ризики містять у собі всі види дозвілля, для яких потрібна майстерність для подолання небезпечних ситуацій. Такі ризики завжди добровільні і припускають наявність особистого контролю над ступенем ризику» [11]. Сприйняття ризику також може варіюватись залежно від суспільства та оточуючого людину середовища.

Схильність до ризиків зменшується, коли людині нав'язують вибір та коли їй доручено прийняти рішення. В таких випадках особистість не хоче ризикувати, тому надалі відповідальність за прийняте рішення може бути покладена саме на неї. Таким чином, у людей в умовах добровільного або нав'язаного вибору виникає двояке відношення до ризику. Якщо людині настирливо рекомендувати прийняття того чи іншого рішення, вона взагалі може відмовитись від його приймання.

На думку А. Ісмаілова, в ризикованих ситуаціях важливу роль відіграє схильність до ризику як особистісна риса характеру. Він говорить, 
що «схильність до ризику може змінюватися залежно від того, як індивід виявився в проблемній ситуації. Якщо він добровільно ставить перед собою мету і приймає рішення для їх досягнення, то його схильність до ризику збільшується. В такому випадку люди сприймають ризик позитивно і готові примиритися з ним заради можливості досягти значущої для себе мети» [5].

Здатність людей потрапляти під вплив різноманітних емоцій, пов'язаних з ризиком, зумовлює появу рішень, які можуть докорінно змінити поведінку особистості. Ситуація ризику передбачає наявність не лише об'єктивних, але і суб'єктивних чинників її буття. Суб'єктивна її частина пов'язана з вибором альтернатив, різним сприйняттям індивідами однієї і тієї ж величини ризику.

Цікавими є погляди щодо цих ситуацій І. Дженіса та Л. Манна, які вказали на те, що прийняття рішення $€$ емоційно напруженим та «гарячим» когнітивним процесом. Вони пояснювали це явище тим, що приймання рішень в умовах ризику протікає на тлі інтенсивних переживань, викликаних дефіцитом часу, високим соціальним контролем та інтенсивним навантаженням. Вони дали своє бачення етапів прийняття рішень у подібних ситуаціях:

1) «етап оцінки завдання (чи великий збиток, якщо нічого не робити);

2) етап огляду варіантів (який з варіантів може розв'язати проблемну ситуацію і достатня кількість альтернатив);

3) етап зважування варіантів (які вимоги пов'язані з можливими варіантами);

4) етап повідомлення про прийняття рішення;

5) етап прийняття рішень, пов'язаних з ризиком» [4].

У своїх науково-теоретичних поглядах вчені також акцентували увагу на тому, що є частина людей, які не бажають приймати рішення, уникати його через емоційну навантаженість та наслідки, які це рішення може мати.

В. Боснюк у своїй роботі, посилаючись на погляди І. Дженіса та Л. Манна, наводить стратегії, які допомагають уникати рішення:

1) «удавати, що нічого не трапилось (нема потреби приймати рішення);

2) використовувати стиль поведінки, який завжди допомагав у важкій ситуації (тобто не вдаватися в особливості ситуації);

3) уникати рішучих дій, яких потребує ситуація, «реалізуватися в сферах», де від тебе нічого не залежить (відхід в бік псевдодіяльністі, хоча ця діяльність буде демонструвати активність людини);

4) людина приступає до збору інформації, яка необхідна для прийняття рішення, але робить це так довго, що ця інформація вже стає непотрібною»[2].
Беручи до уваги дослідження попередньо згаданих вчених І. Дженіса та Л. Манна, Е. Етціоні класифікує та виділяє найбільш поширені моделі та варіанти прийняття рішень:

І. «Захисне ухилення, тобто намагання відкласти рішення на невизначений термін.

II. Гіперреакція, тобто імпульсивне рішення з метою позбавитись стресу.

III. Підвищена пильність, тобто намагання зібрати більше інформації для прийняття рішення» [14].

Під час прийняття рішень в умовах ризику, як попередньо згадувалось, об'єктивні фактори тісно пов'язуються із суб'єктивними, де останні безпосередньо витікають з особливостей характеру та рис особистості. До них належать цілеспрямованість, властивості пам'яті людини, творчі та креативні здібності, структура пізнавальної діяльності, наявність або відсутність визначених правил або стратегій прийняття вибору або альтернативи. Ще один важливий фактор, який впливає на прийняття рішення в умовах ризику, - це час. У разі його браку збільшується емоційне навантаження, людина може намагатись прискорити свій вибір, що в подальшому може бути помилковим та при до небажаних наслідків або ж стрес - фактор спонукає до прийняття коректного рішення.

Щодо правильності прийнятого рішення, то в більшості випадків люди здатні переоцінювати її (ефект надмірної впевненості після прийняття рішення), тому що після даного вчинку людина намагається віднайти в своїй пам'яті ті факти, які б підтверджували його правильність, а не суперечили.

Також враховується вік людини під час прийняття рішень: у молодшому віці людина може приймати будь-яке рішення, в тому числі ризиковане, спонтанно, необдумано, піддаючись імпульсивним поривам. Вже в більш старшому віці рішення приймаються обдумано, з певним острахом за наслідки, зважуючи всі «за» і «проти». Хоча, винятки бувають різні.

У науковій літературі виділяються особистості, які мають зовнішню та внутрішню стратегії прийняття рішень. Представниками таких підходів є Дж. Роттера, М. Мескон, С. Пашкевич. Вони зазначали, що «особи з внутрішньою стратегією пов'язують свої успіхи або невдачі з якостями особистості - здібностями, волею, рівнем інтелекту. Вони характеризуються великою відповідальністю в прийнятті рішень. Особистості з зовнішньою стратегією вважають, що їх перемоги чи невдачі залежать головним чином від зовнішнього середовища. Особи з внутрішньою стратегією більш активні під час пошуку інформації в невизначеній обстановці. Ця група людей більш об'єктивна в оцінці отриманих даних та висновках. Особи з внутрішньою стратегією частіше приймають рішення 
з середнім рівнем ризику та рідше - з більш високим» [1]. Цей вид установок відіграє значну роль у прийнятті рішень в умовах ризику.

3 розвитком соціальних інститутів, зміною соціальних відносин змінюється і те, що рішення частіше та більше приймаються не індивідуально, а колективно, тобто групою. Було визначено, що рівень прийняття рішень в умовах ризику в рамках групи може відрізнятись від ризику, який може допускатись людиною. Наукова література являє собою варіативність опису прийняття рішень групою: «ефект поляризації», «ефект групового мислення», «феномен вивченого дисонансу», «ефект асиметрії якості рішень» [16; 17].

Висновки 3 проведеного дослідження. Прийняття рішення є частиною нашого життя, що досить часто визначає його вектор. Багато вчених та теоретиків розглядають та досліджують це явище, та особливу увагу привертають рішення, які приймаються в умовах ризику.

Приймаючи рішення, людина піддається впливу як об'єктивних, так і суб'єктивних аспектів. Якщо об'єктивні аспекти залежать від зовнішнього та оточуючого середовища, то суб'єктивні - безпосередньо від самої людини, її ментально-психічних рис та особливостей. До них можна віднести цілеспрямованість, властивості пам'яті людини, творчі та креативні здібності, структуру пізнавальної діяльності, наявність або відсутність визначених правил або стратегій прийняття вибору або альтернативи.

Під час прийняття рішень в умовах ризику важливо враховувати такий фактор, як час. Знаходячись в умовах часової обмеженості та умовах ризику та стресу, емоційний стан людини зазнає навантаження, що може вплинути на коректність прийняття рішення та призвести до небажаних наслідків.

\section{ЛІТЕРАТУРА:}

1. Арсеньев Ю.Н. Принятие решений. Интегрированные интеллектуальные системы. Москва : ЮНИТИ. Дана, 2003. 207 с.
2. Боснюк В.Ф., Топчій В.О. Проблема прийняття рішення у ризиконебезпечних ситуаціях. URL: http://www.irbis-nbuv.gov.ua/cgi-bin/irbis nbuv/ cgiirbis_64.exe?I21DBN=LINK\&P21DBN=UJRN\&Z2 $1 \mathrm{ID}=\& S 21 \mathrm{REF}=10 \& S 21 \mathrm{CNR}=20 \& \mathrm{~S} 21 \mathrm{STN}=1 \& \mathrm{~S} 21 \mathrm{~F}$ $\mathrm{MT}=\mathrm{ASP}$ _meta\&C21COM=S\&2_S21P03=FILA=\&2 S21STR=Pekp $2015 \quad 1710$.

3. Гурова Л.Л. Психология мышления. Москва : ПЕР СЭ, 2005. 136 c.

4. Джанис И., Манн Л. Принятие решения. Человеческий фрактор. Москва : Транспорт, 1986. C. 81-104.

5. Исмаилов А. А. Социология риска: принятие решений в условиях риска. URL: https://vestnik. mgimo.ru/jour/article/view/2534

6. Краткий психологический словарь / сост. Л. А. Карпенко ; под общ. ред. А. В. Петровского, М. Г. Ярошевского. Москва : Феникс, 1998. 512 с.

7. Кыштымова И. М. Психосемиотика креативности. Иркутск : Изд-во ИГУ, 2008. 579 с.

8. Леонтьев А. А. Основы психолингвистики. Москва : Смысл, 1997. 287 с.

9. Мещеряков Б. Г., Зинченко В.П.Большой психологический словарь. Еврознак, 2006. 672 с.

10. Плаус С. Психология оценки и принятия решений» решений : пер. с англ. Москва : Филинъ, 1998. 368 c.

11. Ренн О. Три десятилетия исследования риска: проблемы и новые перспективы. Вопросы анализа риска. 1999. № 1. С. 80-99.

12. Рубинштейн С. Л. Основы общей психологии. Санкт-Петербург : Питер, 2000. 712 с.

13. Шавкунова И. С. «Решение» в психологии и экономике: интеграция научных подходов. Психология в экономике и управлении. 2017. Т. 9. № 1. C. 24-33. DOI: 10.17150/2225-7845.2017.9(1).24-33.

14. Этциони Э. Простое решение / пер. с англ. Эфрфективное принятие решений. Москва : Альпина Бизнес Букс, 2006. С. 49-60.

15. American Psychological Association Dictionary of Psychology URL: https://dictionary.apa.org

16. Eysenck M. W., Kean, M. T. Cognitive Psychology. A Student's Handbook. A natural science approach. New York : Psychology Press, 2005. 646 p.

17. Kahneman D., Tversky A. Prospect Theory An Analysis of Decision under Risk. Econometrica. 1979. 47 (2). P. 263-291. 